\title{
Planning and Programming a Hotel
}

\author{
Jan A. deRoos
}

If you are planning a hotel you must balance functional, layout, and aesthetic issues to develop a property that simultaneously meets the needs of the guests, the staff, and the owner. In general, fivestar properties have public areas that are heavily design oriented, with the functional aspects carefully integrated to enhance, yet not dominate the space. However, budget properties tend to favor function and layout over design, for maximum utility. Regardless of how the spaces are configured, the developer must consider and balance many conflicting needs before a design is ready for the contractor's hand. The best examples provide properties that inspire; are safe, efficient, and cost effective; and that maintain their utility and charm through time.

Programming is the process of defining the activities that will be conducted within a hotel, allocating the requisite space, and establishing relationships between the spaces. This is one of the first steps in the development process. While the developer may work with an architect in developing the program, the developer is responsible for creating the program and for ensuring that the building is designed to accomplish the goals set out in the program. In addition to detailing the activities, space allocations, and relationships within the building, a successful program helps to establish the way the building or buildings are situated on a site, the onsite automobile and pedestrian flows, and connections to the external world. In almost all cases, the activities are the starting point. Once the activities are defined, relationships among them are established. Early in the programming process, you can use schematic bubble diagrams to convey both activities and relationships. Figure 21.1 shows a schematic bubble diagram for a hotel with the basic functional relationships.

Note the role of the lobby as a central gathering point serving both the public areas and the back-of-house areas. Once the activities and relationships are established, you can allocate appropriate space to the activity, both direct activity space and space needed to support the activity. For example, a hotel needs space not only for its guestrooms, but also for infrastructure such as the plumbing, mechanical systems (heat and air-conditioning), vertical transportation (stairs and elevators), horizontal circulation (corridors), and service areas for housekeeping. The summary of all the activities, 
relationships, and space allocations in a hotel is called a building program or design brief. The building program is typically broken down as indicated in Figure 21.2.

Figure 21.1

Basic Schematic Relationships

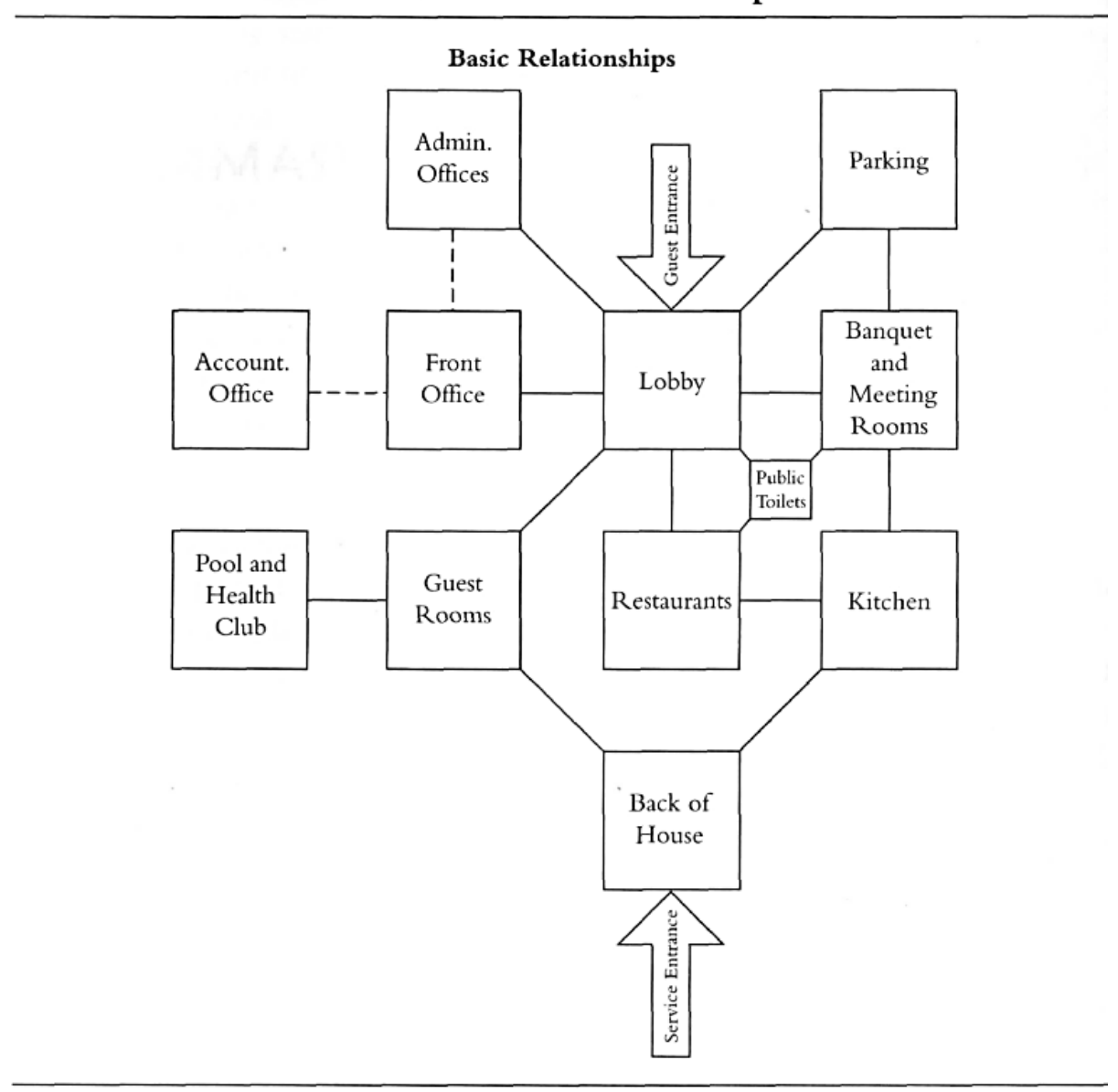

You'll find that the program and its preparation are a collaborative endeavor. While the developer drives the process, input is sought from the design team, the franchisor, the hotel operator, and other consultants. The process is iterative, starting with a rather coarse document containing a provisional list of spaces and a rough outline of space requirements. This is used to establish a preliminary construction and development budget. As the project moves through the feasibility process, the program becomes increasingly refined and becomes the basis for the schematic design prepared by the architectural team. 
Figure 21.2

Contents of a Typical Building Program

- Overall design philosophy including the look and feel of the property

- Site layout and site planning

- Public circulation and lobby

- Guestrooms

- Food and beverage areas

- Meeting space and circulation

- Recreational amenities

- Back-of-house areas

Figure 21.3

Overall Hotel Program

\begin{tabular}{lcccc}
\hline & \multicolumn{2}{c}{ Guestroom Area $\left(\mathbf{f t}^{2}\right)$} & & Total Hotel \\
\cline { 2 - 3 } & Net & Gross & & Gross Area $\left(\mathbf{f t}^{2}\right)$ \\
\hline Motel, economy hotel & 300 & 380 & 420 \\
All-Suite hotel & 430 & 590 & 750 \\
Urban Business hotel & 340 & 480 & 650 \\
Resort & 390 & 540 & 780 \\
Convention hotel & 340 & 480 & 750 \\
\hline
\end{tabular}

Note: Figures are floor area in square feet per guestroom. Guestroom net area is the usable area including bathroom and vestibule. Guestroom gross area includes walls, elevators, stairways, corridors, storage, and mechanical areas on the guestroom floors. Total hotel gross area is the entire hotel, excluding parking.

Figures 21.3 and 21.4 give you a preliminary perspective for a hotel building program. Figure 21.3 provides a useful starting point. ${ }^{1}$ While an economy hotel may have only 420 square feet (39 square meters) of gross hotel area per guestroom, a resort hotel may have almost double the area or 780 square feet (72 square meters). The reason for the size difference is twofold. First, the resort's guestrooms themselves are 30 percent bigger (390 net square feet vs. 300 net square feet). Second, the resort has a much larger percentage of the overall program devoted to public areas and back-of-house areas (10 percent of total hotel gross area for an economy hotel versus 30 percent for a resort hotel). Figure 21.4 shows you how the space allocation varies depending on the type of hotel. ${ }^{2}$

If you're involved in developing a chain hotel, the programming work is greatly simplified. Whether the property is franchised or managed by the chain, the brand will have a set of brand standards and prototype designs that go a long way toward defining the activities, relationships, and space allocations. The developer needs to adapt the prototype to the market and the site, but much of the work has been done by the brand. On the other hand, the developer of a five-star independent resort must start from scratch and think clearly about the program; although a significant amount of 
information comes from the feasibility process, the final program requires careful thinking about the short- and long-term business plan for the hotel.

Figure 21.4

Hotel Space Allocation

\begin{tabular}{lcccc}
\hline & Number of & \multicolumn{3}{c}{ Percentage of Total Hotel Area } \\
\cline { 3 - 5 } & Guestrooms & Guestrooms & $\begin{array}{c}\text { Public } \\
\text { Areas }\end{array}$ & Back-of-House \\
\hline Motel, economy hotel & $<100$ & 90 & 5 & 5 \\
All-suite hotel & $100-200$ & 80 & 12 & 8 \\
Urban business hotel & $100-300+$ & 75 & 14 & 11 \\
Resort & $100-500$ & 70 & 16 & 14 \\
Convention hotel & $300-1,000+$ & 65 & 20 & 15 \\
\hline
\end{tabular}

Note: The number of guestrooms/hotel depends on local market conditions and shows a large variation from country to country. The space allocations (percentages) remain largely the same worldwide.

\section{Programming Guestrooms}

The most fundamental planning for a hotel involves the guestrooms-not only do they account for the bulk of space within a hotel, but a large measure of the hotel experience is in the guestroom. Developing an efficient and effective design of these areas is critical for your initial development budget, but this is also a key to long-term guest satisfaction and operating efficiency. While low-rise hotels with one to three stories typically use a design with guestrooms on both sides of a corridor (the "doubleloaded" slab), high-rise hotels use this configuration along with a variety of rectangular, triangular, and circular tower designs. The choice of guestroom floor layout is driven by design, site, and cost considerations. Figure 21.5 shows the most common guestroom floor types and their overall efficiencies, as indicated by the guestrooms (percent) column. ${ }^{3}$ The most efficient are the double-loaded slab and the offset slab, while the least efficient is the atrium-style arrangement. The presence of all types of slabs is a continuing testament to the fact that design, not efficiency drives floor slab design choice.

The most suitable slab design depends on the circumstances, which include the configuration of the site and the desired visual identity. If your hotel is in a dense urban core, land costs drive the decision to use a tower configuration and often the arrangement of the tower on the site itself. In a resort location, though, the desires to maximize views and to minimize the visual impact of the property generally conspire to drive a low-rise guestroom configuration, which might even be single-loaded if 
there are ocean or other spectacular views. As you can see, developers need to take into account many factors when planning guestrooms. Figure 21.6 provides a summary of things for you to consider. ${ }^{4}$

Figure 21.5

Guestroom Floor Analysis

\begin{tabular}{|c|c|c|c|c|c|}
\hline Configuration & $\begin{array}{l}\text { Rooms per } \\
\text { Floor }\end{array}$ & Dimensions & $\begin{array}{l}\text { Guestrooms } \\
\text { (percent) }\end{array}$ & $\begin{array}{l}\text { Corridor } \mathrm{ft}^{2}\left(\mathrm{~m}^{2}\right) \\
\text { Per Room }\end{array}$ & Comments \\
\hline $\begin{array}{l}\text { Single-loaded slab } \\
\text { 血咅 }\end{array}$ & $\begin{array}{l}\text { Varies } \\
12-30+\end{array}$ & $\begin{array}{l}32 \mathrm{ft} .(10 \mathrm{~m}) \times \\
\text { any length }\end{array}$ & $65 \%$ & $80 \mathrm{ft}^{2}{ }^{2}\left(7.5 \mathrm{~m}^{2}\right)$ & $\begin{array}{l}\text { Vertical core usually not affected by room } \\
\text { module }\end{array}$ \\
\hline 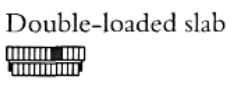 & $\begin{array}{l}\text { Varies } \\
16-40+\end{array}$ & $\begin{array}{l}60 \mathrm{ft} .(18 \mathrm{~m}) \times \\
\text { any length }\end{array}$ & $70 \%$ & $45 \mathrm{ft}^{2}{ }^{2}\left(4.2 \mathrm{~m}^{2}\right)$ & $\begin{array}{l}\text { Economical; length limited to egress stair place- } \\
\text { ment to meet buil/ling code }\end{array}$ \\
\hline 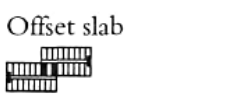 & $\begin{array}{l}\text { Varies } \\
24-40+\end{array}$ & $\begin{array}{l}80 \mathrm{ft} .(24 \mathrm{~m}) \times \\
\text { any length }\end{array}$ & $72 \%$ & $50 \mathrm{ft}^{2}\left(4.6 \mathrm{~m}^{2}\right)$ & $\begin{array}{l}\text { Core is buried, creating less perimeter wall per } \\
\text { room, more corridor because of elevator lobby }\end{array}$ \\
\hline $\begin{array}{l}\text { Rectangular tower } \\
\text { 賉 }\end{array}$ & $16-24$ & $\begin{array}{l}110 \times 110 \mathrm{ft} \\
(34 \times 34 \mathrm{~m})\end{array}$ & $65 \%$ & $60 \mathrm{ft} .\left(5.6 \mathrm{~m}^{2}\right)$ & $\begin{array}{l}\text { Planning issues focus on access to corner rooms, } \\
\text { fewer rooms per floor make core layout difficult }\end{array}$ \\
\hline $\begin{array}{l}\text { Circular tower } \\
\text { a }\end{array}$ & $16-24$ & $\begin{array}{l}90-130 \mathrm{ft} . \\
\text { diameter } \\
(27-40 \mathrm{~m})\end{array}$ & $67 \%$ & $\begin{array}{l}45-65 \mathrm{ft}^{2} \\
\left(4.2-6 \mathrm{~m}^{2}\right)\end{array}$ & $\begin{array}{l}\text { High amounts of exterior wall per room, } \\
\text { difficult to plan guest bathroom }\end{array}$ \\
\hline Triangular tower & $24-30$ & Varies & $64 \%$ & $\begin{array}{l}65-85 \mathrm{ft}^{2} \\
\left(6-7.9 \mathrm{~m}^{2}\right)\end{array}$ & $\begin{array}{l}\text { Central core inefficient due to shape; corner } \\
\text { rooms easier to plan than with square tower }\end{array}$ \\
\hline 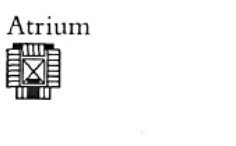 & $24+$ & $90 \mathrm{ft} .+(27 \mathrm{~m})$ & $62 \%$ & $95 \mathrm{ft.}^{2}\left(8.8 \mathrm{~m}^{2}\right)$ & $\begin{array}{l}\text { Open volume creates spectacular space, open } \\
\text { corridors, opportunity for glass elevators; } \\
\text { requires careful engineering for HVAC and } \\
\text { smoke evacuation }\end{array}$ \\
\hline
\end{tabular}

The planning of individual guestrooms is driven by the locale and the target markets for the property. Almost all hotels include a mix of guestrooms, often composed of rooms with one king (or queen) bed, rooms with two double (or twin) beds, and suites of differing configurations. While the bed mix is an inexact science, Figure 21.7 provides a rough guideline for various types of hotels. ${ }^{5}$ Note how the recommended bed mix varies widely depending on the type of hotel. While double-double rooms may make up only 10 percent of a boutique hotel, they could be 75 percent of the beds in a familyoriented resort. It is important that you match the bedroom mix to the market and the marketing plan, as the type of bed configuration has a major impact on guest satisfaction. Single business travelers prefer one bed and like the remaining space devoted to work and lounging space. A family prefers the second bed for their children, although some hotels provide flexibility with a slightly larger room containing a single king (or queen) bed and a sofa that can be converted into a bed.

Once the bed mix is determined, your attention turns to planning the individual room types. Planning guestrooms requires careful consideration of the activities that will happen within the room. Figure 21.8 shows five zones from top to bottom: a lounging or reading zone, a working or dining zone, a sleeping zone, a dressing zone, and a bathroom zone. Good guestroom design anticipates all of these activities, their interrelationships with other areas of the guestroom, and the space needed for each 
activity. Experienced developers know that their input is made via the program; communicating the activities, relationships, and space allocations to assist the design team in their work. ${ }^{6}$

Figure 21.6

Guestroom Floor Planning Considerations

\section{Siting and Orientation}

- Site the guestroom structure to be visible from the road.

- Orient guestrooms to enhance views; "view rooms" command a price premium.

- Where feasible, assess the relative visual impact and construction cost of various guestroom plan configurations.

- Position the guestroom structure to limit its structural impact on the ballroom and other major public spaces.

- Consider solar loads and solar screening, especially for blocks of rooms with east or west exposures.

\section{Floor Layout}

- For economy of construction, organize the guestroom tower or wings so that the guestrooms occupy the maximum amount of the gross floor area.

- Develop the corridor plan to facilitate guest and staff circulation.

- Place the elevator lobby in middle third of the structure to minimize walking distances.

- Provide service elevator, linen storage, and vending in a central location on the guestroom floor.

- Plan corridor width at a mininum of $5.0 \mathrm{ft} .(1.5 \mathrm{~m}), 5.5 \mathrm{ft}$. (1.65 m) optional.

- Significant plumbing economy can result if guest bathrooms are placed back to back.

- Locate handicap-accessible guestroons on lower floors and near elevators.

\begin{tabular}{lccc}
\hline \multicolumn{3}{c}{$\begin{array}{c}\text { Figure 21.7 } \\
\text { Guestroom Mix }\end{array}$} \\
\hline \multicolumn{3}{c}{ Room type as a percent total guestrooms } \\
\cline { 2 - 4 } Type of Hotel & $\begin{array}{c}\text { Double-Double } \\
\text { (or Double-Twin) }\end{array}$ & $\begin{array}{c}\text { Single King } \\
\text { (or Single Queen) }\end{array}$ & Suites \\
\hline Business (downtown) & $30 \%$ & $60 \%$ & $10 \%$ \\
Boutique or lifestyle hotel & 10 & 80 & 10 \\
Suburban/airport hotel & 50 & 45 & 5 \\
Roadside select service hotel & 60 & 40 & 0 \\
Budget hotel & 80 & 20 & 0 \\
Resort/family oriented & 75 & 20 & 5 \\
Resort/couples oriented & 20 & 75 & 5 \\
Convention hotel & 55 & 35 & 10 \\
Conference center & 30 & 65 & 5 \\
All-suite hotel & 30 & 70 & 0 \\
Super-luxury & 20 & 70 & 10 \\
Casino hotel & 45 & 40 & $15+$ \\
\hline
\end{tabular}


Figure 21.8

Activities to Be Anticipated in Guestroom Design

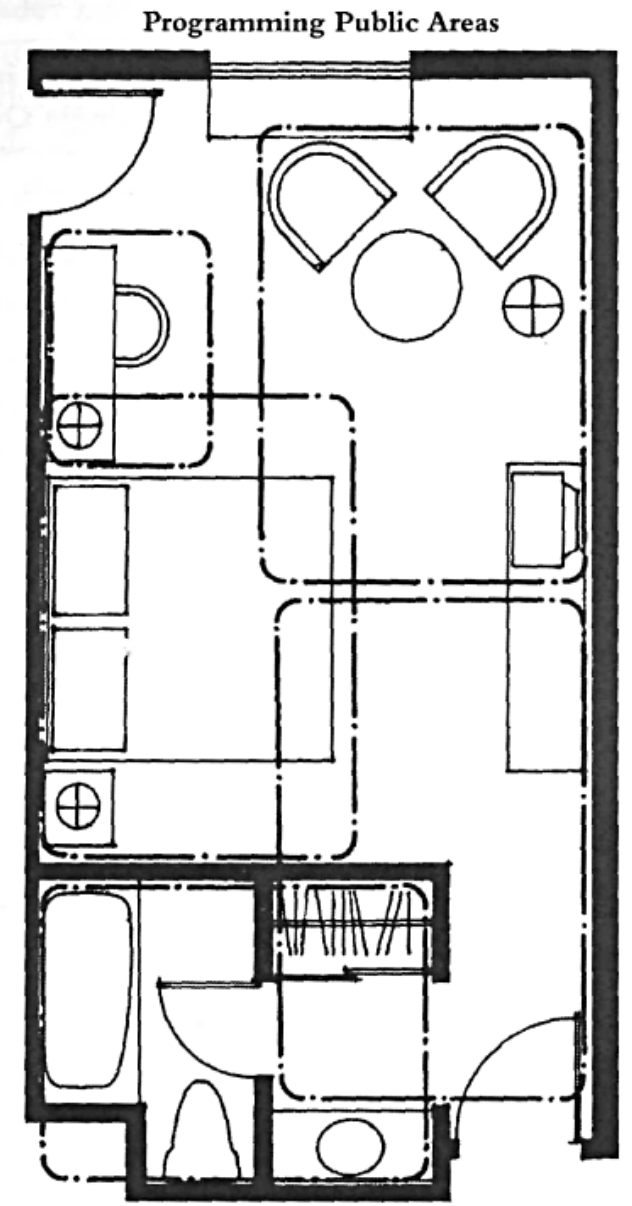

Working within the program and with the developer's vision for the property in mind, the design professionals add an appropriate look and feel for the quality level of the hotel-one that is suitable for the locale and surroundings. As an example, it is typical for guestrooms in tropical resort locations to have tile floors throughout the room, with mats or area rugs adding interest, softening the look and feel, and providing comfort. This would be completely inappropriate for an urban hotel in a temperate climate, where some combination of carpet and wood is appropriate, with tile floors reserved for the bathroom. Another example is that hotels built for vacationers staying more than a few days need much larger closets and storage space than would an urban hotel with an average stay of one to three days.

\section{Programming Public Areas}

The major public areas that you'll need to program are the lobby and public flow space, the food and beverage outlets, and the meeting spaces. These areas are the hotel's "living spaces"; they set the 
stage for other activities, frame the image of property, add interest and amenities to the guest experience, and provide space for the formal and informal meetings that take place in any hotel.

Hotel lobbies have become the most iconic of all hotel spaces. The lobby must function not only as the hotel's "front office," but also as an important transition space. The transition from an often hectic and arduous journey to the security and serenity of the hotel takes place in the lobby. If you think about it, the best lobbies work so well that guests do not even notice the attention to program and planning detail. The reception desk is obvious and inviting, regardless of which entrance the guests use. People circulate effortlessly to the other spaces within the hotel, without feeling lost or disoriented. Figure 21.9 provides a schematic diagram for a lobby with the major connections indicated. ${ }^{7}$

In addition, the lobby program should include the following support functions:

- Clear access to stairs, elevators, or escalators

- Lobby seating, for both individuals and small groups

- Concierge desk and storage, if appropriate

- Front desk administrative areas

- Bell stand and luggage storage

- Public toilets, coatrooms, and house phones

\section{Food and Beverage Programming}

The configuration and number of hotel food and beverage (F\&B) outlets varies widely. At one end of the spectrum are the 20 F\&B outlets in the Jumeirah Beach Hotel in Dubai, and at the other end, the coffee shop or quick-service restaurant that is next to a rooms-only hotel. In addition, standards differ globally. Hotels in the Middle East and Asia generally have a greater number of F\&B outlets than their European and North American counterparts do.

Knowing that hotel F\&B outlets are in competition with excellent local rivals, many small and select-service hotels may have only a single, multipurpose space that serves as a combination breakfast room, coffee bar, and sandwich deli in the morning, and transforms into a casual bar and limited-menu dining setting in the evening. The best designs delight guests, while providing a space- and laborefficient venue. 
Figure 21.9

Lobby Schematic Diagram

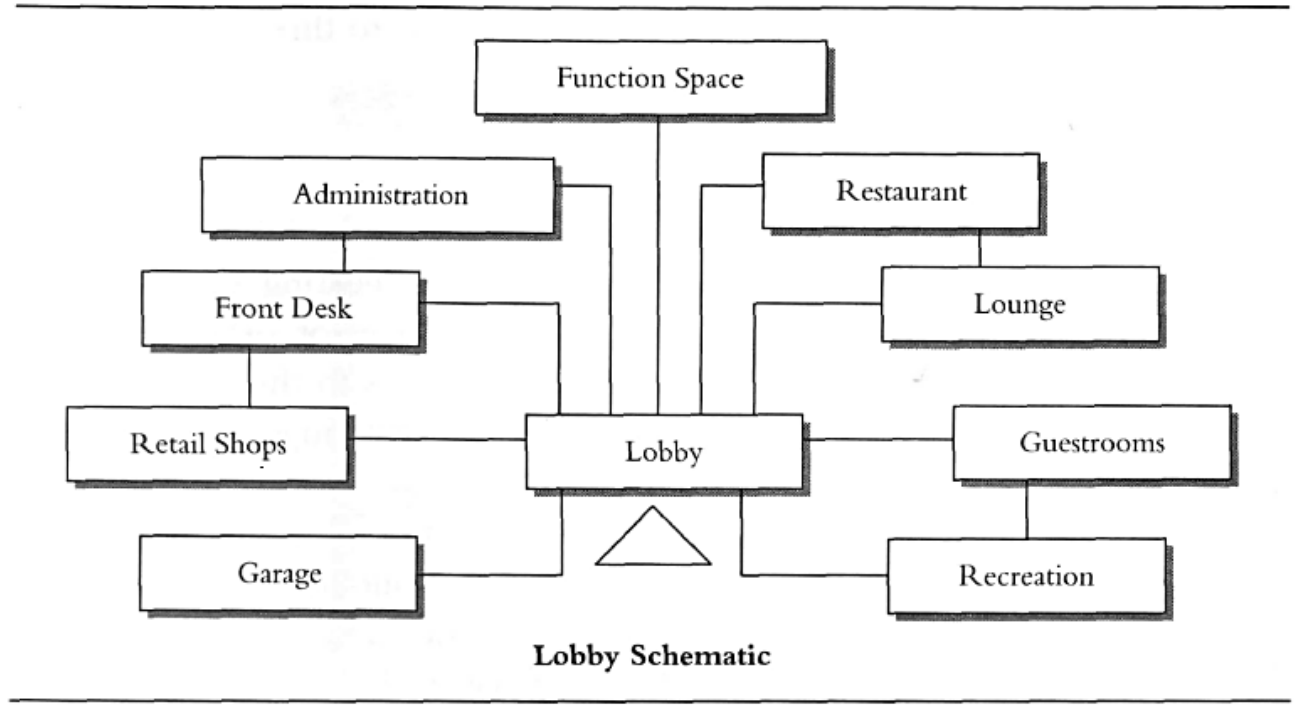

For larger hotels, especially those that are resort or convention oriented, management creates an overall vision for the F\&B operations. The multiple outlets must offer variety, value, and excitement; in general, the program includes fine dining, casual dining, and a set of beverage-oriented outlets with different themes, from quiet lounges to nightclubs. One growing trend you'll find is for hoteliers to partner with celebrity chefs to create signature dining outlets within the hotel (although this arrangement has the potential downside noted in Chapter 18). The celebrity can open a well-located restaurant, and the hotel gets access to customers seeking a unique dining experience, as the restaurant serves both hotel guests and a local clientele.

Programming standards for food and beverage outlets include the following objectives:

- Provide fine-dining venues with direct access to the exterior to maximize street presence and to enhance the restaurant's positioning as a local eatery.

- Locate the hotel's main casual dining restaurant as conveniently as possible in the hotel's main circulation patterns to maximize internal business.

- Conserve back-of-the-house space by sharing kitchens among F\&B outlets, except for a kitchen used by a celebrity chef.

- If possible, provide a shared restaurant and banquet kitchen, again for economy of construction and operation.

- Provide satellite bars with an appropriately sized service area for preparation, storage, and backup. 
- Design restaurants and bars so that sections can be closed off during slow periods to create more intimate venues.

- If possible, provide separate restrooms for each outlet. This is especially true for highvolume beverage operations.

\section{Function Space Programming}

Function space programming, like F\&B programming, varies widely across different types of hotels. The largest hotels in any market have at least one distinct ballroom, smaller meeting rooms, boardrooms, conference rooms, exhibition space, and dedicated banquet rooms; a small hotel might have only a single multipurpose room for all events. A convention hotel or a conference center hotel is created specifically for meetings; for these hotels, the size, configuration, and capabilities of the various function spaces are one of the primary design drivers. Commercial-transient hotels add function spaces to provide an amenity and to broaden the hotel's service offerings. Select-service hotels typically have limited meeting facilities, such as boardroom-type venues.

Working with the management company, the developer is responsible for creating the overall meeting space program, consistent with the hotel's location and primary functions. The schematic diagram in Figure 21.10 provides an overview for a moderately large urban or suburban hotel, say 600 rooms, with a variety of meeting spaces. ${ }^{8}$

Figure 21.10

Function Space Schematic Diagram

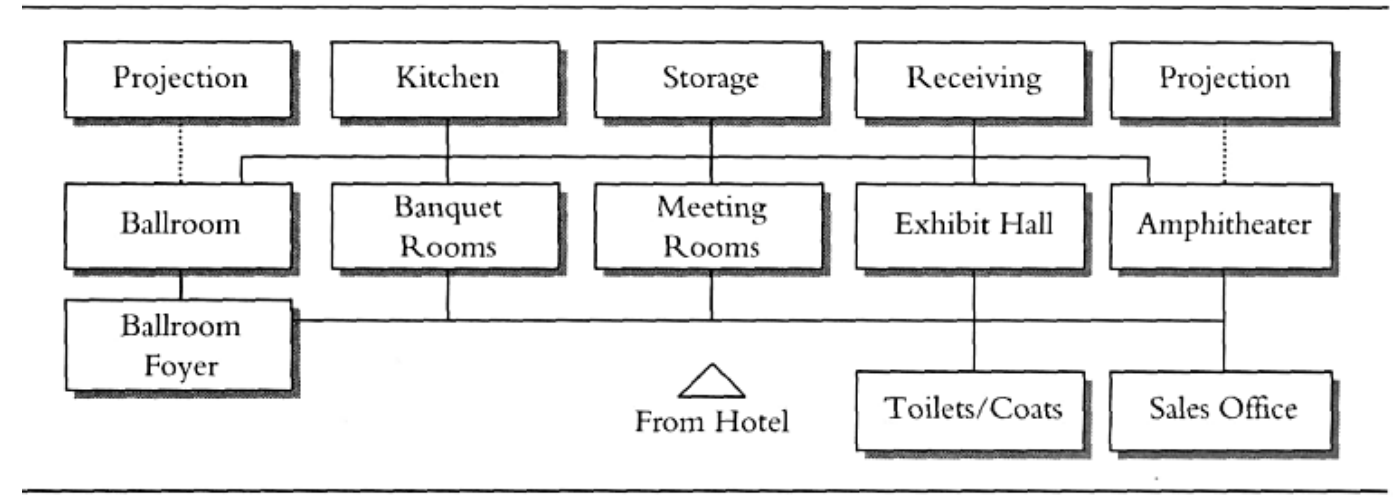

\section{Conclusion}

Hotel development brings dreams to life when you combine great ideas with financial capital. In this chapter, you have seen how to build a bridge that successfully connects great spaces with healthy financial returns. Though complex, the development process offers rewards for those with the skills and 
tenacity to orchestrate the mix of design, construction, capital, and brand decisions that create a great hotel.

You will find that planning and programming are important, but difficult, parts of the hotel development process. Programming a hotel involves defining the activities to be conducted within and surrounding the property, establishing relationships among the activity areas, and allocating an appropriate amount of space for the activities. It is the developer's responsibility to prepare a program that is consistent with a property's vision and positioning. Working with the design team and the hotel's management company, the developer takes the program and develops this into a design that achieves the objectives set out in the program.

\footnotetext{
${ }^{1}$ Adapted from D. Penner, "Operational planning and relationships," Chapter 10 in J. Ransley and H. Ingram, eds. Developing Hospitality Properties and Facilities, 2nd ed. (Oxford, UK: Butterworth-Heinemann, 2004), 195-214. ${ }^{2}$ Ibid.

${ }^{3}$ Adapted from W. Rutes, R. Penner, and L. Adams, Hotel Design, Development, and Planning (New York: Norton, 2001).

${ }^{4}$ Ibid.

${ }^{5}$ Ibid.

${ }^{6}$ Ibid.

${ }^{7}$ Ibid.

${ }^{8}$ Ibid.
} 